\title{
Parvovirus B19 IgG Antibody Measurement
}

National Cancer Institute

\section{Source}

National Cancer Institute. Parvovirus B19 Ig G Antibody Measurement. NCI Thesaurus.

Code C96617.

The determination of the amount of parvovirus B19 IgG antibody present in a sample. 